\title{
Thresholds and Passageways. Stepping Through the Gates of the Other World
}

\author{
NÓRA HENTER \\ ELTE BTK Keleti Szláv és Balti Tanszék, Budapest, Pf. 107, H-1364
}

\begin{abstract}
In Bulgakov's "The Master and Margarita" some of the characters are able to pass from the profane world i.e. their everyday Moscow reality into the sacred (supernatural) one and vice-versa. Of course only a few 'chosen' characters are able to step into the other world, only those who somehow have served it, or deserve it. Passage is only possible in special times and on special places which share the features of the archetypal image of the centre of the world. Several objects, parts of the human abode, such as mirrors, fireplaces, windows gain importance as being kinds of a 'threshold' passing through which characters can get into the sacred world. They represent the boundary between the two worlds, but at the same time they serve as a passageway between them.

Bulgakov chooses these thresholds making use of popular belief and literary tradition, thus making more expressive the fictive world of the novel. The article is a survey of the mirrors or mirroring surfaces (as water for example), fireplaces, windows and Frenchwindows stepping or getting through which does not only mean a simple changing of place but also marks the getting into a completely different world, ruled by other rules than those valid in the world of the atheistic Muscovites of the novel.

Keywords: sacred; profane; threshold; passage; mirror; fireplace; (French)window; centre (of the world)
\end{abstract}

A literary work always means the surpassing of the limit of the given historical reality both to the reader and the writer. Since both of them are human beings the modelled world of the literary work will be somehow based on the writer's and reader's knowledge about it. These two points of view differ, of course, but the magic of reading consists of the ability to enter the game offered by the author through the literary work.

The definition of the fantastic has always been problematic as it can be defined only on the background of reality. Most theoreticians (Caillois, Todorov) agree upon the fact that the fantastic is something that does not submit itself to the physical laws of reality, it intrudes in it and turns it upside-down. A fantastic event is something that cannot be explained within the rules of the reality: either it is an illusion of the senses - and in this case nothing has happened but somebody only had dreamt up or imagined an unusual event - , or there really happened something, but in that case the laws ruling the reality are not valid any more, that is, our knowledge about reality is transformed, we have to reconsider our image of reality. The 20th century relativistic conception of reality makes impossible its use as a basis for a definition like the above-mentioned. That is why Tzvetan Todorov's theory of the fantastic (Todorov 1970) cannot help here. He considered an event to be fantastic if it was perceived as such by the reader 
and defined the fantastic as the hesitation or fear felt by the reader between two possible explanations of the unusual event: as being real or only an illusion of the senses. This reader-dependent definition is rather unrealistic since we are talking about an inherent feature of an existing literary work.

M. Bulgakov's The Master and Margarita is not considered to be a fantastic novel by the critical literature. There are references to fantastic elements used by the author, but it has not yet been studied how the fantastic works in the novel, other aspects of it being considered more important. But trying to extract the fantastic element out of it almost nothing of the story remains. It is not surprising however, that Bulgakov used the fantastic as a literary device in order to speak about other values, other world than that accepted by the Moscow of the 1920s-1930s.

Of course, as I have already pointed out before (Henter 1999), there can be two types of reading, called experimentally sacred and profane. One of these, the 'sacred reading' cancels the fantastic element from the very beginning of the novel. For a true believer the existence of the Satan and his appearance in the human world is not problematic at all. As he believes in miracles, he can read the story without sensing anything fantastic in it. As for the profane reading, though it perceives supernatural/fantastic events as such, it is meant to be altered into a sacred one towards the end of the story. The author leads the reader through the labyrinth created by himself on a way that starts from a profane worldview and step by step proves the existence of a sacred one as being real. This could be called 'the (self-)annihilation' of the fantastic throughout the novel. But this is the theme of a larger study.

In order to make easier the reference to the novel two notions have to be introduced: the 'profane world' referring to the world of the atheistic Muscovites, a wold denying the existence of any supernatural forces that can somehow influence human life, the typical representative of which could be Berlioz, and the 'sacred world' referring to Woland's and Yeshua's world. They are put together because although they represent opposed parties, both of them are parts of the same world, the sacred one. (It could be called mythical, supernatural etc. as well.)

These worlds can be defined mentally, not geographically. The only difference is, that while the profane world only consists of the geographical/earthly Moscow (as the atheistic Muscovites can't accept something else to be real) the sacred one is open above and underneath towards the heaven and the underworld, sharing the model of the archetypal world-image. This means that the same earthly/geographical site, Moscow, can be at the same time sacred and profane, this 'feature' of it depending only on the character (hero or anti-hero) perceiving it. To the atheistic inhabitants of Moscow the city will always remain a profane space full of unexplainable, that is, fantastic events while for the more sensitive (open-minded) characters (such as the Master, Margarita, her maid, Natasha, and to some extent Ivan) the same city offers the experience of the sacred.

This openness above and underneath makes the sacred Moscow the arche- 
typal centre of the world (just like Yershalaim, not occasionally having been referred to as the 'Third Rome' in some historical and literary works) where passage between the three 'cosmic layers' (Earth, Hell/Underworld, Heaven) becomes possible. As it was shown in my article, there are plenty of symbols of axis mundi and centre of the world in the novel: mountains, hills, ladders, and these are the places where the major decisions concerning the protagonists' lives are taken (Henter 1998).

Analysing further these places several objects, parts of the human abode gain importance as being kinds of a 'threshold' passing through which the characters get into the sacred world. As M. Eliade pointed out, the human abode is always situated in the centre of the world and it represents the cosmos, the inhabitated world, 'our world' as opposed to the chaos, the unorganised, unknown and because of this threatening 'other' world, the world of evil spirits and forces:

The threshold is the limit, the boundary, the frontier that distinguishes and opposes two worlds and at the same time the paradoxical place where those worlds communicate, where passage from the profane to the sacred world becomes possible. (...) they are symbols and at the same time vehicles of passage from one space to the other. (Eliade 1987: 24-25)

Beginning with the 'openings' of the human abode, through which one can get out not only from the house but also can enter another world, doors, windows, thresholds, chimneys and fireplaces will be the subjects of my study, as well as other objects or geographical sites which help the characters get in contact with the supernatural/sacred world, as for example mirrors, water surfaces.

In The Master and Margarita, in case of characters belonging to Woland's entourage, is rather common to appear and enter a human abode through a mirror.

Likhodeev's awakening-scene a day after Berlioz' death is full of mirrormotifs. Actually Likhodeev realizes that he is at home by recognizing first the mirror situated between two windows (the window also having the function of a passageway/threshold connecting two worlds).

В полутьмечто-то тускло оесвечивало. Степа наконец узнал трюмо и понял, что он лежит навзничь у себя на кровати, то есть на бывшей ювелиршиной кровати, в спальне (Булгаков 1989: 402).

When he tries to get up he catches sight of himself in the same mirror and then he notices an unknown man dressed in black (Woland) next to the mirror.

According to popular belief the mirror reflects the soul (the real self) of the person looking into it. Those who are not reflected in mirrors have lost their soul (a motif widely used in literature e.g. Hoffmann, Chayanov), that is they are dead, they belong to the underworld. The mirror is also a tool of witchcraft; magic mirrors can show the future or the truth about faraway people or actions, or they show things differently from the way mortals can see them or they show more than people are able to see by themselves (Róheim 1984). 
Later on, before their 'real' appearance in Likhodeev's bedroom Koroviev and Behemoth show themselves first in the mirror hanging in the hall:

Тут Степа повернулся от аппарата и в зеркале, помещавшемся в передней (...) отчетливо увидел какого-то странного субьекта - длинного, как жердь, и в пенсне (...). А тот отразился и тотчас пропал. Степа в тревоге поглубже заглянул в переднюю, и вторично его качнуло, ибо в зеркале прошел здоровеннейший черный кот и также пропал (Булгаков 1989: 410).

The last of the 'reflections' will be Azazello, who simply steps out of the bedroom mirror making Likhodeev faint:

Прямо из зеркала трюмо вышел маленький, но необыкновенно широкоплечий, в котелке на голове и с торчащим изо рта клыком, безобразящим и без того невиданно мерзкую физиономию (Булгаков 1989: 411).

Margarita's first appearance in the novel in chapter 13 is also a mirrorscene. After having an unusual dream about the Master and having read the pages left from his novel, she is reflected in the mirror sitting at her dressing table and looking at his photo:

Утирая слезы, Маргарита Николаевна оставила тетрадь, логти положила на подзеркальный столик и, отражаясь в зеркале, долго сидела, не спуская глаз с фотографии (Булгаков 1989: 546).

On the same day, in the evening, she is sitting naked in front of the same mirror, waiting for Azazello's phone-call. This mirror is the witness of her metamorphosis, she goes through both an inner and outer change. A completely different woman is looking back from the mirror: she became a witch. The light of the full moon will follow her through the night - the moon being also considered by popular belief a mirror reflecting the sunshine. The full moon is a motif that is present at the most important events of the 'sacred world'.

In popular belief, the full moon is a sacred time, time of suitable for witchcraft, when witches, evil forces and dead souls are meeting in a special sacred space, on special places of these earthly site (Pócs 1989).

Margarita's revenge in Latunsky's flat does not spare the wardrobe having a mirror in it and it is soon followed by the breaking of the windows not only in Latunsky's flat but in the whole house. In popular belief the breaking of the mirror - or that of glasses - brings bad luck to its owner; it often means the owner's death (Róheim 1984: 258-259). Rimsky, the sales manager of the Variety Theatre, fleeing from Moskow, threatened to death by the midnight visit of Hella and the vampire-Varenuha, catches sight of his eyes reflecting madness in the rear-view mirror of the taxi:

Седока трепало на сиденье, ив осколке (!) зеркала, повешанного перед шофером, Римский видел то радостные шоферские глаза, то безумные свои (Булгаков 1989: 486).

Margarita is shown her new self/image in a mirror before the ball: she appears as the Queen of the Realm of Shades: 
Какая-то сила вздернула Маргариту и поставила перед зеркалом, и в волосах у нее блеснул королевский алмазный венец. Откуда-то явился Коровьев и повесил на грудь Маргариты тяжелое в овальной раме изображение черного пуделя на тяжелой цепи. Это украшение чрезвычайно обременило королеву. (...) Но кое-что вознаградило Маргариту за те неудобства, которые ей причинила цепь с черным пуделем. Это - та почтительность, с которою стали относиться к ней Коровьев и Бегемот (Булгаков 1989: 587).

The change of clothes, again, is a change of identity: the "crown jewels" (decorated with the same symbols as Woland's) convey power to the person wearing them.

As it has been mentioned above, broken glasses can have the value of bad omen. The image of Koroviov's cracked pince-nez is the second in the line opened by the windows around the like at the Patriarshie Prudi reflecting the last beams of the sun 'going forever down for Berlioz' and ending with Berlioz' death accompanied by the jangling-clinking of the windowglasses of the tram. Later, in Margarita's metamorphosis-scene the glass of Margarita's watch will be cracked by the golden jar containing Azazello's cream, which falls onto it.

Water can also function as a mirror, as it can reflect things just like mirrors. The most relevant bathing-scene is that of Ivan's in the Moskva-river. This image is full of symbols refferring to the initiation ritual present in most religions since ancient times, reminding the archetypal fight of the hero with the evil force (the ruler of the Underworld) living in the depth of the waters. The changing of the clothes makes the image more expressive. The water is cold and hostile (Ivan thinks for a while that he cannot even come again to the surface), and its black, oily-smelling surface reflects the 'broken' (!) lights of the streetlamps.

Однако выскочить удалось, и, отдуваясь и фыркая, с круглыми от ужаса глазами, Иван Николаевич начал плавать в пахнущей нефтью черной воде меж изломанных зигзагов береговых фонарей (Булгаков 1989: 381).

The image of the water (river) reappears several times through the novel, reminding the 'other world'. For example, the psychiatric clinic where the Master and Ivan meet each other is on the bank of a river.

За сеткой в окне, в полуденном солнце, красовался радостный весенний бор на другом берегу, а поближе сверкала река (Булгаков 1989: 421).

The river/water is the border between the earthly word and the underworld/ the world of the dead in several mythologies. In Russian folklore it is the living space of evil souls (Lotman) and in popular belief the sites of Witches' Sabbath are clearings situated close to a river (Pócs 1989).

Margarita's flight ends on the bank of a river: she feels the closeness of water, so she stops to have a bath. Later on it turns out that she has arrived to the place of a Sabbath where creatures of fairy-tales and myths are having a meeting. Her bathing-scene is a transformation of that of Ivan's. Both of them are going through an initiation, but while Ivan's bathing resembles a struggle in a hostile environment, Margarita's seems to be a real pleasure: 
Легкое ее тело, как стрела, ввонзилось в воду, и столб воды выбросило почти до самой луны. Вода оказалась теплой, как в бане, и вынырнув из бездны, Маргарита вдоволь наплавалась в полном одинрчестве ночью в этом реке (Булгаков 1989: 71).

Margarita's maid, Natasha, who had spread the leftovers of Azazello's cream on herself, has already had a bath and she went back to Moscow to announce there Margarita's arrival. The Sabbath is taking place on small island, the island also being a symbol of a different world, cut from the rest of the world by water.

A parodic repetition of these bathing-scenes can be found in the description of the ball, where the revived late poisoners and killers are taking a bath in a basin full of alcoholic drink (first it is champagne, then brandy). And again, Margarita and the Master have to cross a brook on their way to their last abode, a friendly little house lit by candlelights, given to them by Yeshua.

Another variant of the bathing-scenes is the blood-shower taken by Margarita before the ball begins. This gives her power and beauty, just like Azazello's cream. The drinking of blood at the culminating point of the ball is part of this theme, and it is an initiation-motif as well.

After al these, it can be said that is not a mere chance that Woland makes his first appearance in the Patriarshie Prudi, on the shore of a pond. It is not by chance, either, that Margarita, thinking of suicide, has the river in her mind. On the embankment of the Moskva river Ivan has to descend a few stairs to the water, as if he made some steps downwards to the Underworld. The stairs, as a symbol of axis mundi, emphasize that this place shares the features of the centre of the world where passage to the Underworld is possible. Ivan, indeed, has an experience of the 'other' world for a short time - while having a bath in the river. This initiation-like bathing will be the turning-point of his life: he is enabled to get an experience of the sacred, to understand some things which remain unexplainable to the inhabitants of the profane world.

Fireplaces can also take the role of a passageway between the profane and the sacred world, as they are openings of the house: in popular belief evil souls often get into human abodes through the chimney (Pócs 1989).

The fireplace in Likhodeev's flat turns into the Gate of Hell for the time of he ball: the late killers and poisoners return from the realm of the dead through this piece of furniture. This must be the huge fireplace in late Berlioz' room in the flat shared with Likhodeev, the central piece of the 'underwordly' decorated room:

Войдя туда, куда его пригласили, буфетчик даже про дело свое позабыл, до того его поразило убранство комнаты. Сквозь цветные стекла больших окон (...) лился необыкновенный, похожий на церковный, свет. В старинном громадном камине, несмотря на жаркий весенний день, пылали дрова. А жарко между тем нисколько не было в комнате, и наоборот, входящего охватывала какая-то погребная серость. (...) Был стол, при взгляде которой богобоязненный буфетчик вздрогнул: стол был покрыт церковной парчой. (...) Пахло не только жареным, но еще какими-то крепчайшими духами и ладаном (...) (Булгаков 1989: 532). 
In addition to all these a huge black tomcat - Behemoth - and an owl are present at the dialogue between Andrei Fokich and the black magician, which repeats the steps of Berlioz' fatal dialogue about his death with the same person, at the beginning of the novel.

The fireplace mentioned above just like the stairs always present in the description of the way to this place are additional symbols of the centre of the world, showing that it is not by chance that Woland has chosen this place as his residence. The fact that this flat is a place where passage between the sacred and the profane world is possible would explain some of the strange disappearances of the people living in this flat, as well.

The fireplace in the Master's basement flat is also given a central place. It makes the little flat a friendly home for the Master and his lover and gives the comfort needed for the peaceful, intellectual work of the Master, and finally, it is this fireplace where the manuscript of the Master's novel is thrown, but in fact, as we find it out later, it is thrown into the sacred world, where 'manuscripts never burn' and where it takes only a few minutes for Behemoth to present the manuscript to its writer.

In Bulgakov's novel windows and Frenchwindows frequently appear as thresholds between the two worlds and each time when someone steps through a window a passage from one of the worlds into the other one is made. In shortage of space, only the most relevant scenes will be mentioned in the present article.

Margarita, the witch, saying goodbye to her former life leaves her house flying out through the window, spending a short time sitting on the windowledge in the moonlight making fun of the conservative, narrow-minded Nikolai Ivanovich. She also gets into Latunsky's flat through the window, this time already as a representative of the sacred world, a witch who takes revenge. People do not understand what happens around them as their profane world does not admit a solution or explanation like this.

It is interesting, however, that trying to calm a child who is crying in the same house, she tells him that she does not exist, he is only dreaming her, thus connecting her new existence with the world of dream, which is a world of miracle, a part of the sacred world. Dreams reveal a lot to people who are able to understand them. The theme of dream and insanity as altered consciousness giving people the experience of the transcendental has already been studied by critics. I would only like to mention the fact that the Master (he could be called Ivan's initiator) enters his disciple's room in Stravinsky's clinic through a Frenchwindow. He is already considered to be insane and is already in contact with the sacred world, the existence of which Berlioz tried to deny so vehemently. The immediate result of his nightly visit is Ivan's dream, that is the second part of Yeshua's story. This dream offers the poet the opportunity to cast a glance into the miraculous world of the sacred, so far unknown to him.

Margarita and the Master, already dead in the profane world will come through this Frenchwindow to say goodbye to Ivan. It is night again and Ivan is 
half-asleep, half under the influence of sedatives, not completely conscious but in a state of mind that makes him more sensitive to the signals coming from the sacred world, the existence of which became obvious to him.

Another relevant scene is the midnight visit of Hella and Varenukha (already turned into a vampire) to Rimsky's room at the Variety Theatre. To Rimsky, the ultimate proof of Varenukha's metamorphosis is the fact that he has no shade, a motif borrowed from popular belief. According to this belief, people having no shade as well as those having no reflection in a mirror (E. T. A. Hoffmann used this latter motif in one of his short stories) are dead souls (Róheim 1984).

Hella tries to get in through the window, while Varenukha is 'guarding' the door, making impossible Rimsky's flight. This scene is desribed as Rimsky, the protagonist could perceive it: a real ghost-story in the style of E. A. Poe with all its accessories - and a rooster, the crow of which will make the ghosts disappear and help the desperated manager to escape.

Another relevant escape is that of Woland's companions from the burning flat in Sadovaya street - through the window, again:

В то время, как на Садовой послышались пугающие сердце колокольные удары на быстро несущихся со всех частей города красных длинных машинах, мечущиеся во дворе люди видели, как вместе с дымом из окна пятого этажа вылетели три темных, как показалось, мужских силуэта и один силуэет обнаженной женщины. (Булгаков 1989: 672)

A lot of Woland's 'guests' enter or leave his room through the window, such as the Master, when he is 'called' by the Ruler of the Shades after the ball or Aloizy Mogarich, who is taken out through the window by a wind. Azazello, as well, when he comes for the last time to the Master's basement flat to take them away with him, enters the room through the window.

The moonlight that always follows the characters belonging to the sacred world marks a sacred time, different from the historical time of mankind. In popular belief, the full moon, as well as the time of storms, so frequently appearing in the novel are times favourable for evil souls to appear on earthly sites (Pócs 1989). At such times evil souls 'snatch', the humans - this is the case of Varenukha, kidnapped during a storm, or that of Nikolai Ivanovich, Margarita's neighbour, who arrives to the ball transformed into a hog, as Natasha's flying vehicle. Both of them have to serve the supernatural force, which often happens to humans who go to the wrong place in the wrong time - that is to a place where witches or fairies meet for a Sabbath in times known as 'fairy-times' (Pócs 1989). This sacred time is a circular time. Every time when it is full moon Ivan will be nervous and will suffer from insomnia and will be thinking or dreaming of the sacred world, of his Master, of Yeshua and Pilate.

The (Mid)night represents also a periodically repeating time, when dead souls and vampires come to visit human beings (as for example Hella and Varenukha), and such is the dusk, the time when Woland and his companions 'arrive' to Moscow. 
The time of the full moon in spring is a 'multiple' sacred time: this is the 'anniversary' of Yeshua's discussion with Pilate, which took place during the old Jewish religious feast, the Pascha and at this time, centuries ago, was Christ crucified, this date marking one of the greatest religious feasts of the Christian world. This biblical story, becoming a myth, is retold over and over again, making the people listening to it enter the sacred (mythical, circular) time - just like it happens to Ivan while listening to Woland's story about Yeshua. He can't sense the passing of the time: he is wondering at the end of the story if he has dreamt it all up or not. As M. Eliade pointed out, listening to a myth represents the reactualization of a sacred event that took part in the mythical past and by means of rites a religious man can pass from ordinary temporal duration to sacred time (Eliade 1987:68).

The Satan's spring ball of the full moon called also the ball of a hundred kings takes place every year - as Woland himself says to Margarita and can be considered a festival. As some of the critics have pointed out (Balassa 1988; Faryno 1985), the Satan's appearance on the earth is not occasional, since according to Russian Orthodox religious belief the Satan had been the emperor of the world for three days, from Christ's crucifixion till his resurrection on Easter Sunday, and he is ruling on the earth at this time every year. During the ball - which starts at midnight (!) - Margarita notices that the moon doesn't change its place on the sky, that is, time has stopped. In fact, she stepped out from linear historical time into sacred time, which happens to her again when she and the Master are poisoned by Azazello at the end of the novel, in order to rise again in the sacred space and time. The Satan's ball is organized every year: with the same guests and with a queen, a hostess chosen from the local women wearing the name of Queen Margo. The only thing that changes from year to year is the place where the ball is held.

Margarita is susceptible to witchcraft and she is superstitious enough to believe in the magic of dreams: she takes her unusual dream about the Master for a prophecy. On that day she acts with the feeling in her soul that something has to happen. She makes a rite of her own: she goes for a walk and sits down on the same bench where she was sitting together with the Master, exactly a year before, and is waiting for something to happen. This shows, that she believes in cyclical repetitions and in 'sacred' places. She has got a circular concept of time which is accentuated by the narrator, as well: in order to emphasize the importance of her freedom while his husband is away, the narrator expresses the three days' time as three times twenty-four hours, directing the attention to the importance of magic numbers (which has been dealt with by critical literature - e.g. Круговой 1979) and the repetitive nature of those 24 hours.

Муж уехал в командировку на целых три дня. В течение трех суток она предоставлена самой себе, никто не помешает ей думать о чем угодно, мечтать о том, что ей нравится. (Булгаков 1989: 545) 
The abundance of the images connected with passage between the two worlds and the immense variety of images which go back to folklore making use of most of the elements once appeared in literature (back to medieval poetry see Галинская 1985) offer the reader an inexhaustible source of further connections and relationships of this well-constructed world-system making him to rebuild it like a puzzle. This newly rebuilt fictive world-image each time will become a little-bit richer, more colourful, will show itself more properly to the reader, amazing him with its complexity, making him to return to the novel again and again, trying to find out more about a world which shows itself only to the initiated... Thus the reading of the novel becomes a rite of initiation itself — this time to the reader.

\section{Literature}

BALASSA P. Az ördögregény két huszadik századi változata a Doktor Faustus és A Mester és Margarita példáján. Medvetánc 1988/1.

Булгаков М. Избранные произведения в двух томах, 2. Киев 1989.

CAILLOIS R. În inima fantasticului. Bucureşti, 1971.

CAILLOIS R. Eseuri despre imaginație. Bucureşti 1975.

ELIADE M. The Sacred and the Profane. New York 1987.

FARYNOJ. История о Понтии Пилате: Russian Literature, 1985/XIII.

Галинская И. Л. Албигойские ассоциации в «Мастере и Маргарите» М. А. Булгакова: Известия АН СССР, Серия литературы и языка 44 (1985).

HENTER N. Középpont-motívumok Bulgakovnál. A Mester és Margarita: Dolce Filologia. Budapest 1998.

HENTER N. Csodalátók a hangyabolyban: Napút 1999/7.

Круговой Г. Гностический роман Булгакова: Новый журнал 1979/134.

PÓCS É. Tündérek, démonok, boszorkányok. Budapest 1989.

RÓHEIM G. A büvös tükör. Budapest 1984.

TODOROV Tz. Introduction a la littérature fantastique. Paris 1970. 